\title{
PENGEMBANGAN MEDIA PEMBELAJARAN BERBASIS ADOBE FLASH UNTUK MATA PELAJARAN FIKIH DALAM UPAYA MENINGKATKAN HASIL BELAJAR SISWA
}

\author{
Ahmad Fajri Lutfi ${ }^{1}$, Asep Usamah ${ }^{2}$ \\ ${ }^{1}$ Pendidikan Teknologi Informasi dan Komunikasi, STKIP Muhammadiyah Kuningan \\ ${ }^{2}$ Pendidikan Guru Sekolah Dasar, STKIP Muhammadiyah Kuningan \\ email:ahmadfajrilutfi@upmk.ac.id \\ email:a_usamah79@upmk.ac.id
}

Received: 27/08/2019, Accepted: 28/08/2019, Published: 29/08/2019

\begin{abstract}
ABSTRACK
The purpose of the study was to determine the increase in the ability of student learning outcomes by using Adobe Flash-based learning media. The population in this study were class XI.A MAN 2 Kuningan and XI.B MAN 2 Kuningan academic year 2018/2019. Selection of samples by purposed random sampling. This research produces interactive multimedia-based figh learning media in the form of Adobe flash, which contains basic figh accompanied by multimedia elements such as elements of video, sound, animation and other elements to support multimedia systems that enable students to be enthusiastic and interested in Pembelajaran Fikih Berbasis Adobe Flash (PFBAF). The experimental class is taught with Adobe Flash learning, while the control class is taught with classical learning. Data retrieval was obtained with the results of the pretest and posttest to obtain data on students motivation ability values which were then analyzed by the average difference test. Based on the results of the study, the results of the increase in students motivating reasoning ability using Adobe Flash increased significantly.

Keyword: interactive multimedia, adobe flash, fiqh.
\end{abstract}

\begin{abstract}
ABSTRAK
Tujuan penelitian adalah untuk mengetahui peningkatan kemampuan minat hasil belajar siswa dengan menggunakan media pembelajaran berbasis Adobe Flash. Populasi dalam penelitian ini adalah siswa Kelas XI.A dan XI.B MAN 2 Kuningan Tahun Pelajaran 2018/2019. Pemilihan sampel dengan cara purposed random sampling. Penelitian ini menghasilkan media pembelajaran fikih berbasis multimedia interaktif dalam bentuk Adobe Flash, yang memuat ilmu fikih dasar disertai dengan unsur multimedia seperti unsur video, suara, animasi, dan unsur lainnya untuk mendukung sistem multimedia yang memungkinkan anak didik berantusias dan berminat terhadap Pembelajaran Fikih Berbasis Adobe Flash (PFBAF). Kelas eksperimen diajar dengan pembelajaran Adobe Flash, sedangkan kelas kontrol diajar dengan pembelajaran klasikal. Pengambilan data diperoleh dengan hasil pretest dan postest untuk mendapatkan data nilai minat siswa yang kemudian dianalisis dengan uji perbedaan rata-rata. Berdasarkan hasil penelitian dbperoleh hasil peningkatan minat siswa dengan menggunakan Adobe Flash meningkat secara signifikan.
\end{abstract}

Keyword: multimedia interaktif, adobe flash, fikih. 


\section{A. PENDAHULUAN}

Perkembangan ilmu pengetahuan juga teknologi komputer dewasa ini semakin menunjukkan kemajuan yang sangatlah pesat. Pemanfaatannya hampir meliputi berbagai aspek dan lapisan. Salah satunya yaitu ditandai dengan makin maraknya instansi-instansi dan juga sekolah-sekolah yang menerapkan teknologi komputer atau teknologi informasi.

Multi media adalah sebagai bagian dari sistem informasi atau teknologi informasi yang dapat menjawab informasi bersifat interaktif dan menampilkan unsur animasi, unsur suara, unsur tulisan, unsur gambar serta keterangan tentang informasi yang lebih efektif juga efisien.

Pengembangan media pembelajaran fikih berbasis Adobe Flash ini merupakan pengembangan penelitian sebelumnya. Dimana peneliti menggunakan metode baru, juga penambahan fitur dan materi baru dalam aplikasi multimedia tesebut. Metode baru yang akan digunakan dalam penilitian ini adalah metode (quasi experiment) dan juga pengambilan data yang dilakukan menggunakan proses pre-test dan post-test, dan yang terakhir sebagai pengembangan aplikasi multimedia sebelumnya, peneliti akan menambahkan fitur baru seperti halnya fitur permainan, gerakan sholat, dan unsur lainnya yang mendukung sistem multimedia.

Sebagaimana dijelaskan di atas, keberhasilan proses pembelajaran dipengaruhi oleh berbagai faktor. Memilih media pembelajaran yang tepat adalah salah satu kunci keberhasilan dalam proses pembelajaran. Salah satu aspek yang dapat digunakan untuk mengukur ketepatan media pembelajaran yang diterapkan oleh guru adalah dengan mengetahui respon siswa terhadap media pembelajaran tersebut. Dengan karakteristik media flash yang dapat diterapkan dalam semua materi fikih, memudahkan siswa untuk memahami materi yang diajarkan karena disajikan dalam bentuk audio visual serta bervariasinya penyajian media flash sebagai aplikasi pada pembuatan, pengolahan dan manipulasi berbagai materi pelajaran sehingga menarik minat siswa dalam pembelajaran fikih.

Diharapkan media pembelajaran Adobe Flash mendapatkan respon positif dari siswa sehingga media pembelajaran ini dapat dijadikan salah satu alternatif media pembelajaran yang dapat digunakan oleh seorang guru fikih dalam proses pembelajaran.

Berdasarkan hal tersebut, maka peneliti tertarik untuk melakukan 
penelitian terkait dengan media pembelajaran fikih berbasis Adobe Flash (PFBAF), sehingga judul penelitian ini adalah "Pengembangan Media Pembelajaran Berbasis Adobe Flash untuk Mata Pelajaran Fikih dalam Upaya Meningkatkan Hasil Belajar Siswa”.

\section{B. TINJAUAN PUSTAKA}

Penelitian ini tentunya sudah banyak dilakukan dan diteliti oleh banyak orang. Penelitian ini sendiri merupakan pengembangan penelitian sebelumnya berupa rancangan sebuah aplikasi fikih, namun pada penelitian sebelumnya masih menggunakan metode sederhana, pengambilan data dan prosesnya hanya menggunakan metode wawancara dan kuisioner, begitupun dengan aplikasi atau software Adobe Flash tersebut, fitur hanya mengacu pada materi fikih.

Pengembangan penelitian akan difokuskan terhadap metode baru, yaitu metode $\mathrm{R}$ \& $\mathrm{D}$ (research \& development), Penelitian ini merupakan penelitian quasi experiment (eksperimen semu). Sampel tidak diambil secara acak. Subjek sampel merupakan kelompok belajar di kelas. Apabila susunan kelas siswa diacak maka dikhawatirkan akan mengganggu aktivitas belajar, pengambilan pemrosesan data juga akan dilakukan dengan pre-test juga post-test. Sementara akan ditambahkan fitur-fitur tambahan seperti game edukasi, gerakan shalat, dan fitur lainnya yang mengandung unsur mata pelajaran fikih juga unsur multimedia. Tentunya pengembangan ini adalah hasil dari kesimpulan penelitan sebelumnya.

\section{Media Pembelajaran}

Kehadiran media mempunyai arti yang cukup penting, karena dalam kegiatan tesebut, ketidak jelasan bahan yang disampaikan dapat dibantu dengan menghadirkan media sebagai perantara. Walaupun tujuan awal dari pembelajaran itu sudah baik, akan tetapi jika tidak didukung oleh media yang tepat, tujuan yang baik tersebut sangat sulut untuk tercapai dengan baik. Sebuah media dalam pembelajaran akan mempengaruhi sampai tidaknya suatu informasi secara lengkap dan tepat sasaran, serta mempengaruhi hasil akhir dari proses pembelajaran tersebut. ${ }^{1}$ Lebihh lanjut Unang Wahidin juga mengatakan, di sisi lain perkembangan ilmu pengetahuan dan teknologi semakin mendorong upaya-upaya pembaharuan dalam pemanfaatan hasil-hasil teknologi dalam proses belajar mengajar. Sehingga para

1 Unang Wahidin dan Ahmad Syaefuddin. (2018). Media Pendidikan dalam Perspektif Pendidikan Islam. Edukasi Islami: Jurnal Pendidikan Islam, 07(1). hlm. 48. 
pedidik dituntut agar mampu menggunakan berbagai jenis media pendidikan. Di samping itu, pendidik juga dituntut untuk dapat mengembangkan keterampilan membuat media pedidikan yang akan digunakannya apabila media tersebut belum tersedia. Untuk itu pendidik harus memiliki pengetahuan dan pemahaman yang cukup tentang media pendidikan. ${ }^{2}$

Kata media berasal dari bahasa Latin, yang artinya merupakan bentuk jamak dari kata medium. Unang Wahidin mengatakan, secara harfiyah media memiliki arti "perantara" atau "pengantar". Demikian pula dalam bahasa Arab, media berasal dari kata "wasaali" yang artinya "perantara" atau "pengantar", 3 berarti sesuatu yang terletak di tengah antara dua pihak atau sesuatu alat di antaranya adalah grafik, fotografi, elektronik, atau alat-alat mekanik untuk menyajikan, memproses, dan menjelaskan informasi lisan atau visual. ${ }^{4}$ Unang Wahidin mengatakan bahwa media merupakan alat bantu yang digunakan dalam proses pembelajaran

2 Unang Wahidin dan Ahmad Syaefuddin. (2018). hlm. 48.

Unang Wahidin. (2018). Implementasi Literasi Media dalam Proses Pemebelajaran Pendidikan Agama Islam dan Budi Pekerti. Edukasi Islami: Jurnal Pendidikan Islam, 07(2). hlm. 232.

4 Sri Anita. (2009). Media Pembelajaran. Surakarta: Yuma Pustaka. untuk menyalurkan pesan berupa materi pembelajaran dari guru kepada peserta didik. $^{5}$ Berbeda dengan pendapat tersebut, bahwa media pembelajaran adalah segala sesuatu yang dapat menyampaikan dan menyalurkan pesan dari sumber secara terencana sehingga tercipta lingkungan belajar yang kondusif di mana penerimanya dapat melakukan proses belajar secara efisien dan efektif. ${ }^{6}$

Hasil dari semua pengertian di atas, tentunya bahwa media memiliki peranan yang penting untuk mendukung proses pembelajaran. Materi pembelajaran berbasis teknologi informasi dan komunikasi juga dapat disampaikan melalui media. Keberadaan media itu memang menuntut masyarakat tidak terkecuali para peserta didik untuk mengikuti trend perkembangan zaman khususnya dibidang komonikasi. Tetapi apabila perkembangan teknologi tidak dibunakan sebagaimana mestinya, dengan kata lain hanya sebatas trend dan digunakan untuk hal-hal yang tidak baik, tentu akan berdampak pada tindakantindakan asusila. Bahkan keberadaan teknologi ini juga bisa membuat orang kecanduan dan asyik berada dalam

\footnotetext{
${ }^{5}$ Unang Wahidin. (2018). hlm. 233.

${ }^{6}$ Yudi Munadi. (2013). Media Pembelajaran: Sebuah Pendekatan Baru. Jakarta: Gang Persada Pers.
} 
kehidupan dunia maya. ${ }^{7}$ Apalagi jika materi yang diberikan dirangkai sedemikian rupa, dengan menggunakan media Adobe Flash sehingga proses pembelajaran bisa berjalan dengan baik dan dengan situasi dan kondisi yang tidak menegangkan baik bagi siswa maupun bagi pengajar.

Ade Wahidin mengutip perkataan Al-Albani berkaitan dengan urgensinya media, "Allah S.W.T. telah mensyariatkan jalan dan sarana untuk mendapatkan ilmu, dan hal ini telah mewujud di alam realita dengan adanya sarana-sarana yang dapat mendekatkan suara, seperti HP. Lebih lanjut Ade Wahidin mengatakan, sarana pendidikan terakhir yang dikonsepkan Al-Albani adalah media cetak. Urgensinya lebih ditekankan kepada para pendidik supaya memiliki wawasan kekinian, sehingga dapat memberikan jawaban yang solutif dan akuran sesuai dengan zamannya. ${ }^{8}$

\section{Multimedia Interaktif}

Hasan Basri Tanjung mengatakan, bahwa menurut Ahmad Tafisr "pendidikan Islam adalah corak

${ }^{7}$ Edi Suryadi, M. Hidayat Ginanjar, dan M. Priyatna. (2018). Penggunaan Media Sosial Whatsapp dan Pengaruhnya Terhadap Disiplin Belajar Peserta Didik pada Mata Pelajaran Pendidikan Agama Islam. Edukasi Islami: Jurnal Pendidikan Islam, 07(1). hlm. 3

${ }^{8}$ Ade Wahidin. (2016). Pemikiran Pendidikan Al-Albani. Edukasi Islami: Jurnal Pendidikan Islam, 05(9). hlm.1261. pendidikan yang khas dan mulia. Pendidikan, metode, materi, media, lingkungan, sarana, tujuan, dan unsur lainnya jelas dan akurat untuk dijadikan model oleh siapa pun dan dimana pun. Kegunaan pendidikan Islam nampak dari tujuannya, yakni menjadikan manusia yang baik. Kualitas baik manusia ditentukan oleh pandangan hidupnya, bila hidupnya berupa agama, maka manusia baik itu adalah manusia baik menurut agama. ${ }^{9}$ Pendidikan diadakan dengan tujuan untuk lebih memanusiakan manusia agar derajatnya lebih tinggi daripada binatang. ${ }^{10}$

Kedudukan media di sini sepenuhnya melayani kebutuhan belajar siswa (pola bermedia). Artinya, untuk beberapa hal media pembelajaran dapat menggantikan fungsi guru terutama sebagai sumber belajar, karena belajar memiliki peranan yang sangat penting dalam kehidupan manusia. Memang manusia terlahir sebagai makhluk yang lemah yang tidak mampu berbuat apaapa serta tidak mengetahui apa-apa, akan tetapi melalui peroses belajar itu dalam fase perkembangannya manusia bisa dan mampu mengusai skill

\footnotetext{
Hasan Basri Tanjung. (2015). Menyelamatkan Nasib Anak Bangsa dengan Pendidikan Islam. Edukasi Islami: Jurnal Pendidikan Islam, 04(08). hlm. 1030.

${ }^{10}$ Hasan Basri Tanjung. (2015). hlm. 1031.
} 
(kemahira/keterampilan)

maupun

pengetahuan. ${ }^{11}$ Oleh karena itu, belajar memiliki peranan yang sangat penting dalam kehidupan manusia, dan salah satu media yang dapat menjalankan fungsi demikian adalah progam multimedia interaktif (selanjutnya kita sebut multimedia interaktif), mengungkapkan kelebihan media interaktif sebagai media pembelajaran. Edi Suryadi dkk. mengungkapkan bahwa media memberikan manfaat secara positif bagi penggunanya. Edi Suryadi dkk. juga mengatakan, sebab itulah media sosial sangat berguna untuk alat komonikasi yang semakin efektif dan efesien, di samping sebagai media komunikasi, dapat juga berfungsi untuk meningkatkan jalinan sosial, karena dengan media sosial seseorang bisa tetap berkomunikasi dengan jarak jauh. $^{12}$

Kelebihan media interaktif tersebut, antara lain sebagai berikut. ${ }^{13}$

a. Interaktif. Sesuai dengan namanya, program ini dirancang untuk dipakai oleh siswa secara individual (belajar mandiri).

b. Memberikan iklim afeksi secara individual. Karena dirancang

${ }^{11}$ Edi Suryadi, M. Hidayat Ginanjar, dan M. Priyatna. (2018). hlm. 8.

${ }^{12}$ Edi Suryadi, M. Hidayat Ginanjar, dan M. Priyatna. (2018). hlm. 7.

${ }^{13}$ Yudi Munadi. (2013). khusus untuk pembelajaran mandiri kebutuhan siswa secara individual terasa terakomodasi, termasuk bagi mereka yang lamban menerima pelajaran. Karena multimedia interaktif mampu memberi iklim yang lebih bersifat afektif dengan cara yang lebih individual, tidak pernah lupa, tidak pernah bosan, sangat sabar dalam menjalankan instruksi, seperti yang diinginkan.

c. Meningkatkan motivasi belajar. Dengan terakomodasinya kebutuhan siswa, siswa pun akan termotivasi untuk terus belajar

d. Memberikan umpan balik. Multimedia interaktif dapat menyediakan umpan balik (respon) yang segera terhadap hasil belajar yang dilakukan oleh peserta didik.

e. Karena multimedia interaktif diprogram untuk pembelajaran mandiri, maka kontrol pemanfaatan sepenuhnya berada pada penggunanya.

\section{Pembelajaran Fikih}

Fikih secara etimologi merupakan "paham yang mendalam". Secara terminologi merupakan ilmu tentang hukum-hukum syar'i yang bersifat amaliah yang digali dan ditemukan dan dalil-dalil yang tafshili. Ruang lingkup pembelajaran fikih untuk madrasah 
ibtidayah meliputi syahadad, thaharah, shalat, puasa, zakat, ibadah haji, makanan dan minuman, muamalat, jenazah, dan mawaris. ${ }^{14}$

Rahendra Maya mengungkapkan, tujuan pendidikan Islam secara general yang lebih ringkas dan mudah diingat. ${ }^{15}$ Lebih lanjut Rahendra Maya menyebutkan bahwa menurut Al-Kîlanî adalah melahirkan insan pembelajar yang berdedikasi tinggi, yaitu insan yang mampu merealisasikan visi-misi pendidikan Islam, atau mengantarkan peserta didik mencapai kemajuan insaniyah yang paripurna. Yaitu sampai ke derajat "bentuk transformatif yang sebaikbaiknya" seperti yang diistilahkan dalam Alquran, dimana tujuan secara general ini dapat dinyatakan sebagai realisasi visi-misi pendidikan Islam yang paling utama. ${ }^{16}$

Pengarahan pembelajaran fikih di madrasah menganut sistem spiral, yakni semua pokok-pokok hukum Islam diajarkan, namun pendalaman dan keluasan materi di sesuaikan dengan tingkat perkembangan siswa dan jenjang pendidikan.

Pencapaian tujuan pembelajaran diperlukan suatu kondisi yang mampu

14 Amir Syarifuddin. (2009). Ushul Fiqih. Jakarta: Kencana.

${ }^{15}$ Rahendra Maya. (2018). Implikasi Relasi Eksploratif ('Alâqah Al-Taskhîr) dalam Pendidikan Islam: Telaah Filosofis Atas Pemikiran Mâjid 'Irsân Al-Kîlanî. Edukasi Islami: Jurnal Pendidikan Islam, 07(2). hlm. 247.

${ }^{16}$ Rahendra Maya. (2018). hlm. 247. memfasilitasi agar siswa terdorong untuk aktif berpartisipasi dalam proses pembelajaran sehingga siswa terbantu untuk mempelajari dan menguasai kemampuan dan atau nilai-nilai baru. Dalam proses tersebut diperlukan guru yang mampu memberikan keteladanan, membangun kemauan, dan mengembangkan potensi dan kreativitas peserta didik.

Implikasi dari prinsip ini adalah pergeseran paradigma proses pendidikan, yaitu dari paradigma pengajaran ke paradigma pembelajaran. Kondisi yang perlu dikembangkan dalam proses pembelajaran menurut Permendiknas No. 41 Tahun 2007 tentang Standar Proses untuk Pendidikan Dasar dan Menengah bahwa: Proses pembelajaran pada satuan pendidikan diselenggarakan secara interaktif, inspiratif, menyenangkan, menantang, memotivasi peserta didik untuk berpartisipasi aktif, serta memberikan ruang yang cukup bagi prakarsa, kreativitas, dan kemandirian sesuai dengan bakat, minat, dan perkembangan fisik serta psikologis peserta didik.

Tujuan pembelajaran fikih adalah untuk mencapai keridhaan Allah S.W.T. dengan melaksanakan syari'ah-Nya di muka bumi ini. Adapun tujuan lainnya adalah agar nantinya siswa mengetahui hukum-hukum 
dalam Islam dan mampu menerapkannya dalam kehidupan sehari-hari.

Dalam Islam, pendidikan merupakan hal yang fundamental, dan tujuan yang akan dicapai dalam pendidikan Islam adalah seimbang antara kehidupan dunia dan akhirat serta tidak ada perbedaan antara laki-laki dan perempuan, sehingga setiap muslim baik itu laki-laki maupun perempuan mempunyai kewajiban dan tanggungjawab yang sama untuk mencari ilmu dan mempunyai kesempatan yang sama untuk mendapatkan pendidikan. $^{17}$

Sebagai suatu sarana, pendidikan dapat difungsikan untuk mengarahkan pertumbuhan dan perkembangan hidup manusia (sebagai makhluk pribadi dan social) kepada harapan dan tujuan yang merupakan titik optimal kemampuan seorang hamba yaitu untuk memperoleh kesejahteraan hidup, baik lahir maupun bathin di dunia dan kebahagiaan hidup di akhirat. $^{18}$

\section{Adobe Flash CS6}

Adobe Flash CS6 merupakan software yang memiliki kemampuan menggambar sekaligus menganimasikannya, serta mudah

17 Aas Siti Sholichah. (2018). Teori-Teori Pendidikan dalam Islam. Edukasi Islami: Jurnal Pendidikan Islam, 07(1). hlm. 29.

18 Rahendra Maya (2016). Revitalisasi Keteladanan dalam Pendidikan Islam: Upaya Menjawab Peluang dan Tantangan Pendidikan Islam di Era Masyarakat Ekonomi ASEAN (MEA). Edukasi Islami: Jurnal Pendidikan Islam, 05(9). hlm. 1186. dipelajari. Adobe Flash tidak hanya digunakan dalam pembuatan animasi, tetapi pada zaman sekarang ini Adobe Flash CS6 banyak juga digunakan untuk keperluan lainnya seperti dalam pembuatan game, presentasi, membangun web, animasi pembelajaran, bahkan juga dalam pembuatan film. ${ }^{19}$

Animasi yang dihasilkan Adobe Flash CS6 adalah animasi berupa file movie. Movie yang dihasilkan dapat berupa grafik atau teks. Grafik yang dimaksud disini adalah grafik yang berbasis vektor, sehingga saat diakses melalui internet, animasi akan ditampilkan lebih cepat dan terlihat halus. Selain itu, Adobe Flash juga memiliki kemampuan untuk mengimpor file suara, video, maupun file gambar dari aplikasi lain.

\section{METODE PENELITIAN}

\section{Metode Penelitian}

Metode penelitian yang digunakan merupakan model pengembangan $\mathrm{R} \& \mathrm{D}$ (research \& development), dimana model research and development digunakan untuk menghasilkan produk tertentu, sekaligus menguji keektifan implementasi produk tersebut. $^{20}$

19 Madcoms. (2012). Kupas Tuntas Adobe Flash Profesional CS6. Yogyakarta: CV Andi Offset.

20 Sugiyono. (2009). Metode Penelitian Pendidikan Pendekatan Kuantitatif, Kualitatif, dan $R \& D$. Bandung: Alfabeta. 
Tahap Pendahuluan

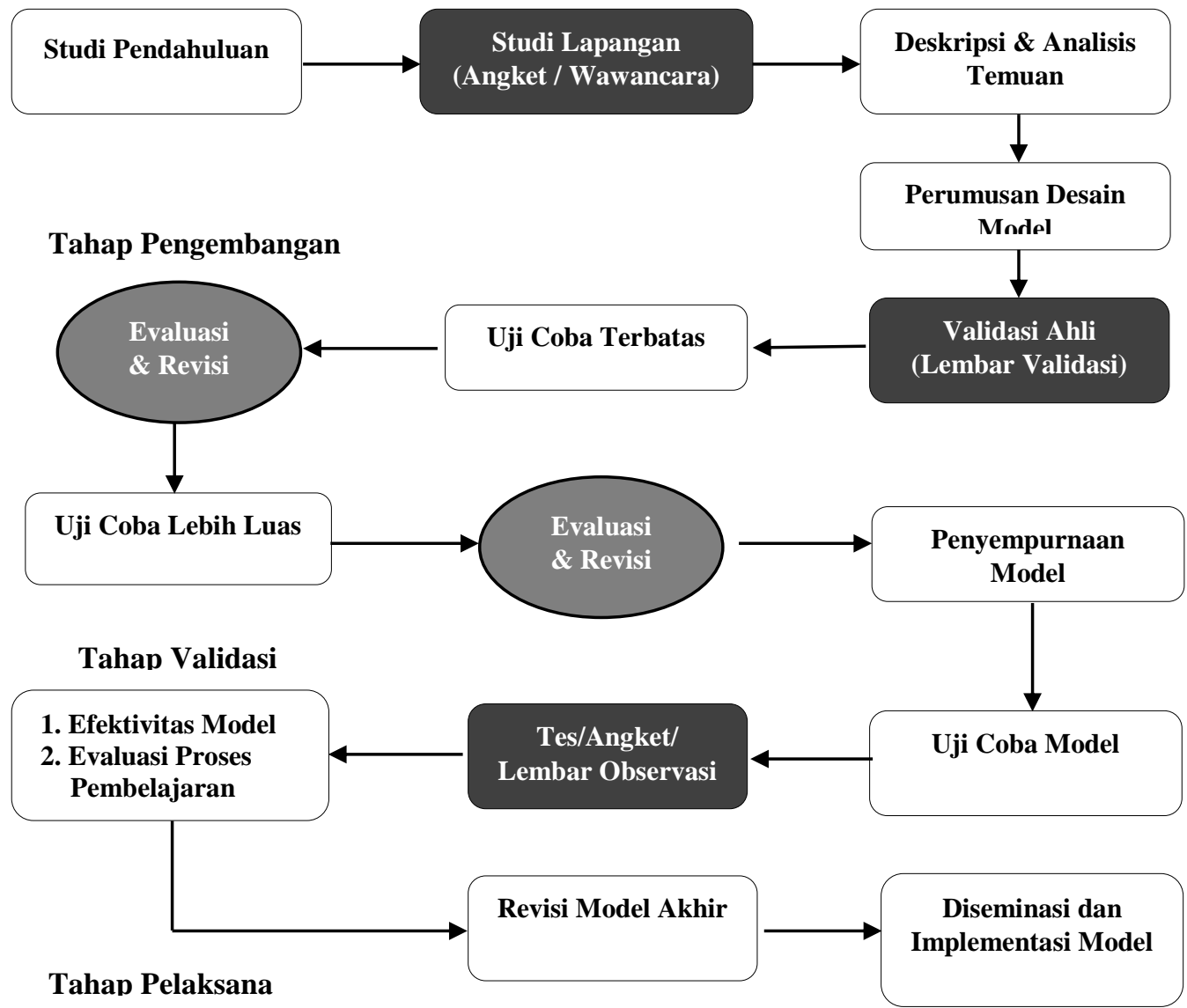

\section{Gambar 1. Alur Penelitian Research and Development}

\section{Desain Penelitian}

Desain penelitian ini merupakan One Group Pretest-Posttes Group Design, dimana desain penelitiannya digambarkan sebagai berikut:

$$
\begin{array}{|lll|}
\mathrm{O}_{1} & \mathrm{X} & \mathrm{O}_{2} \\
\hline
\end{array}
$$

Keterangan:

X : Treatment yang diberikan (penggunaan aplikasi PFBAF)

$\mathrm{O}_{1} \quad$ : Nilai Pretest (sebelum diberi treatment)

$\mathrm{O}_{2}$ : Nilai Posttest (setelah diberi treatment)

\section{Populasi dan Sampel}

Populasi dalam penelitian ini adalah siswa kelas XI A MAN II Kuningan sebagai kelas kontrol dan siswa kelas XI B MAN II Kuningan sebagai kelas eksperimen Tahun Pelajaran 2018/2019. Kelas eksperimen diajar dengan pembelajaran fikih berbasis multimedia.

\section{Instrumen Penelitian}

Data dalam penelitian ini akan dikumpulkan melalui tes kemampuan minat, observasi, kuisioner, dan wawancara. Observasi dilakukan untuk melihat aktivitas 
siswa dan guru selama proses pembelajaran berlangsung di kelas eksperiman yang diamati melalui pedoman pada lembar observasi. Sedangkan data yang berkaitan dengan sikap siswa dalam model pembelajaran berbasis Adobe Flash CS6 dikumpulkan melalui angket skala sikap siswa dengan model skala Likert. Sementara itu, wawancara bertujuan untuk mengetahui jawaban subjek tentang permasalahan dalam pembelajaran secara lisan.

\section{Teknik Pengumpulan Data}

Adapun langkah-langkah yang peneliti tempuh untuk mengumpulkan data adalah sebagai berikut:

a. Pemberian tes awal (pretest), yaitu untuk mengetahui minat siswa sebelum diberi perlakuan (treatment).

b. Pemberian perlakuan (treatment) yang berbeda pada kedua kelas.

c. Pemberian tes akhir (posttest), yaitu untuk mengetahui hasil dari pemberian perlakuan (treatment).

d. Pemberian angket respon siswa, yaitu untuk mengetahui respon siswa terhadap model pembelajaran berbasis Adobe Flash CS6.

\section{Analisis Data}

Salah satu bagian penting yang tidak kalah penting dari tahapan penelitian dalam R\&D adalah melakukan uji keefektifan dan uji efisiensi. Uji keefektifan digunakan untuk membuktikan apakah model mampu mencapai tujuan yang telah ditetapkan atau tidak. Pengukuran efektif dan tidaknya suatu model dilakukan dengan membandingkan skor awal dalam pretest dengan skor akhir dalam posttest. Di samping itu, peneliti juga harus membandingkan skor posttest kelompok kontrol dengan skor posttest kelompok treatment, sehingga dapat disimpulkan apakah terdapat perbedaan skor antara kelompok treatment dan kelompok kontrol.

Sebelum melakukan uji keefektifan, ada beberapa tahapan uji statistik yang harus dilakukan oleh peneliti di antaranya: uji normalitas dan uji homogenitas. Uji normalitas berfungsi untuk mengetahui apakah sebaran data responden berdistribusi normal ataukah tidak. Uji normalitas akan berpengaruh pada penggunaan alat test statistik dalam uji keefektifan model, apakah akan menggunakan statistik parametrik atau non parametrik.

Uji homogenitas digunakan untuk mengetahui apakah kelompok responden berasal dari populasi yang sama atau tidak. jika data hasil perhitungan pada uji normalitas menunjukkan bahwa distribusi data adalah normal, maka analisis statistik yang digunakan untuk uji keefektifan 
model statistik parametrik. Sebaliknya, jika data berdistribusi tidak normal maka uji keefektifan model menggunakan statistik non parametrik.

\section{a. Uji Statistik Keefektifan Model}

Statistik parametrik untuk uji keefektifan model dengan menggunakan SPSS adalah melalui uji $\mathrm{t}$ ( $\mathrm{t}$ test) menggunakan rumus Paired Samples $t$ Test. Berikut adalah hipotesis uji Paired

\section{Samples t-Test:}

$\mathrm{H}_{0}$ : Tidak terdapat perbedaan rata-rata peningkatan akhlak di antara siswa sebelum dan sesudah menggunakan aplikasi PFBAF.

$\mathrm{H}_{1}$ : Terdapat perbedaan rata-rata peningkatan akhlak di antara siswa sebelum dan sesudah menggunakan aplikasi PFBAF.

Adapun statistik uji nya:

$H_{0}: \mu_{1}=\mu_{2}$

$$
H_{1}: \mu_{1} \neq \mu_{2}
$$

Statistik uji yang digunakan untuk mengukur perbedaan rata-rata jika data yang dihitung berasal dari satu kelompok dan datanya berdistribusi normal, maka digunakan rumus Paired Sample T-test, sedangkan apabila datanya tidak berdistribusi normal maka menggunakan rumus Wilcoxon Signed Rank Test. Data yang dianalisis adalah perbedaan rerata pretest dan posttest.
Sedangkan jika peneliti akan melakukan penghitungan uji beda rata-rata skor posttest pada dua kelompok yang berbeda, maka digunakan rumus Mann Witney $U$ Test untuk statistik non parametrik dan rumus Independent Sample $t$ Test untuk statistik parametrik.

\section{b. Uji Statistik Efisiensi Model}

Dalam menguji efisiensi model, peneliti menggunakan hasil angket penilaian aplikasi PFBAF dalam mengevaluasi efisiensi model, angket efisiensi model. Peneliti dapat menghitung jumlah skor total dari penilaian karakter yang dilakukan oleh subjek kemudian menghitung rerata penilaian efisiensi model.

\section{HASIL PEMBAHASAN}

Sebelum dilakukan uji perbedaan ratarata, maka diteliti terlebih dahulu normalitas dan homogenitas sampel sebagai uji asumsi dasar penelitian, berdasarkan hasil uji normalitas didapatkan hasil:

Tabel 1. Uji Normalitas Data

\begin{tabular}{|l|r|r|r|r|r|r|}
\hline \multirow{2}{*}{} & \multicolumn{3}{|c|}{$\begin{array}{c}\text { Kolmogorov- } \\
\text { Smirnov }\end{array}$} & \multicolumn{3}{c|}{ Shapiro-Wilk } \\
\cline { 2 - 7 } & $\begin{array}{c}\text { Statis } \\
\text { tic }\end{array}$ & df & Sig. & $\begin{array}{c}\text { Statist } \\
\text { ic }\end{array}$ & df & Sig. \\
\hline Gain Kontrol &, 094 & 26 &, $200^{*}$ &, 966 & 26 &, 530 \\
\hline $\begin{array}{l}\text { Gain } \\
\text { Eksperimen }\end{array}$ &, 109 & 26 &, $200^{*}$ &, 963 & 26 &, 456 \\
\hline *. This is a lower bound of the true significance. \\
\hline \\
a. Lilliefors Significance Correction \\
\hline
\end{tabular}

$$
\text { Berdasarkan hasil pengujian }
$$
normalitas diketahui nilai Sig. sebesar 0,200 karena nilai sig. > 0,05, maka dapat disimpulkan bahwa baik data peningkatan 
hasil belajar siswa baik kelas kontrol eksperimen berdistribusi normal. Selanjutnya data diuji dengan menggunakan uji homogenitas.

Tabel 2. Uji Homogenitas Data

\begin{tabular}{|r|r|r|l|}
\hline Levene Statistic & \multicolumn{1}{c|}{ df1 } & df2 & Sig. \\
\hline 2,175 & 1 & 50 & 0,147 \\
\hline
\end{tabular}

Berdasarkan hasil pengujian homogenitas diperoleh nilai sig. upaya minat sebesar 0,147. Karena semua nilai Sig. $>0.05$, maka kedua data tersebut homogen. Dikarenakan semua data memenuhi uji asumsi dasar yaitu normal dan homogen, maka pengujian selanjutnya menggunakan uji statistika parametris.

Tujuan penelitian yang pertama adalah mengetahui perbedaan rata-rata kemampuan minat siswa, antara siswa yang memperoleh pembelajaran Adobe Flash dan siswa yang menerima pembelajaran konvensional. Sebelumnya berdasarkan hasil pengujian normalitas dan homogenitas, hasil menunjukkan data berdistribusi normal data dan homogen sehingga pengujian hipotesis dilanjutkan menggunakan uji t. Berikut hasil uji t pada tabel 4:

\section{Tabel 3 Uji Perbedaan Rata-Rata Hasil Belajar Siswa}

\begin{tabular}{|c|c|c|c|c|c|}
\hline $\begin{array}{l}\text { Learning } \\
\text { Group }\end{array}$ & $\mathbf{n}$ & Mean & $\mathbf{t}$ & Sig. (1-tailed) & $\mathbf{H}_{\mathbf{0}}$ \\
\hline Kontrol & 26 &, 4927 & & & \\
\cline { 1 - 2 } Eksperimen & 26 &, 5925 & $-2,597$ & 0,024 & Rejected \\
\hline
\end{tabular}

Berdasarkan hasil pengujian pada Tabel 3 diperoleh nilai probabilitas atau sig. (one-tailed) sebesar 0,024 lebih kecil dari $\alpha=0,05$ sehingga Ho ditolak, artinya terdapat perbedaan rata-rata minat siswa yang signifikan antara siswa yang menerima pembelajaran Adobe Flash dengan siswa yang mendapat pembelajaran konvensional, dari hasil pengolahan data terlihat rata-rata hasil belajar siswa kelas eksperimen lebih tinggi dari kelas konvensional.

Hasilnya menunjukkan bahwa siswa yang belajar dengan menggunakan media pembelajaran Adobe Flash memiliki ratarata kemampuan motivasi atau minat yang lebih tinggi daripada siswa yang menggunakan pembelajaran konvensional. Hasil ini dimungkinkan karena melalui pembelajaran Adobe Flash, siswa difasilitasi dalam unsur multimedia, seperti sound, animasi, dan video dibangun berdasarkan kemampuan minat, sehingga siswa memperoleh pemahaman yang lebih baik. Misalnya, bagaimana siswa menemukan konsep rotasi dan dilatasi pada gambar 1. Melalui pembelajaran Adobe Flash, siswa diberi kesempatan untuk memahami pergerakan objek berupa animasi dan video, siswa belajar untuk menganalisis dengan animasi dan video agar siswa lebih mudah mengkomunikasikan berbagai informasi yang mereka lihat. Dengan menggunakan software Adobe Flash, hasilnya muncul sebagai berikut: 


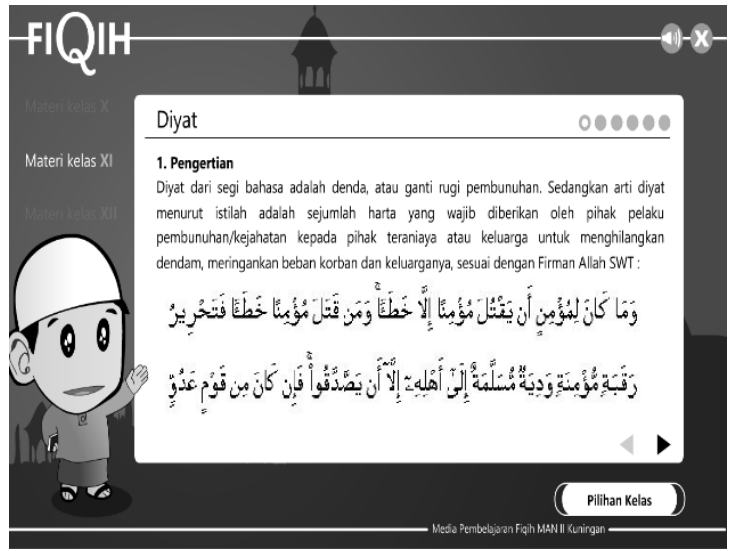

Gambar 2. Tampilan Media Pembelajaran Fikih Berbasis Adobe Flash (PFBAF)

Selain pada gambar 1 di atas yang menampilkan materi, peneliti juga memberikan fitur game edukasi sebagai salah satu upaya untuk menarik motivatsi dan minat siswa. Game edukasi ini berisi tentang panduan sholat bergerak atau gambar animasi, berikut ini disajikan salah satu upaya untuk menarik minat siswa:

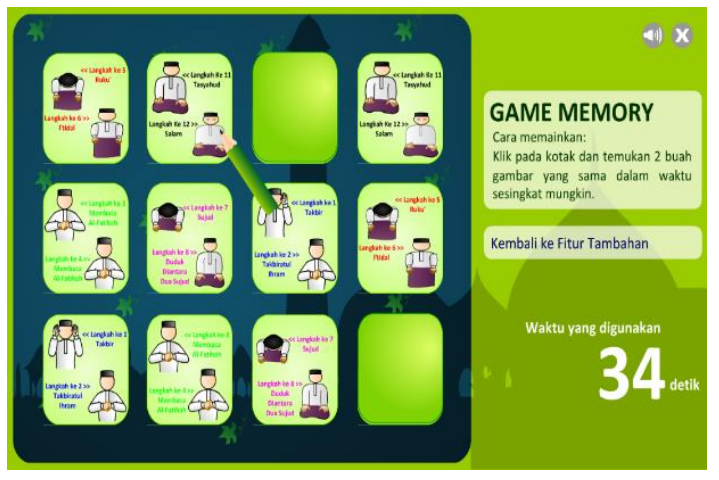

\section{Gambar 3. Game Edukasi Panduan} Sholat

Dari beberapa contoh di atas, siswa dapat menyimpulkan konsep praktik agama Islam. Pembelajaran berbasis komputer melalui software memberikan pengguna sarana untuk mengembangkan berbagai ide dan kekuatan imajinasi dalam membangun bentuk visualisasi. ${ }^{21}$ Belajar dengan menggunakan media pembelajaran Adobe Flash memberikan kesempatan bagi siswa untuk lebih memahami fikih, dalam hal ini guru memberikan kesempatan kepada siswa untuk mengembangkan kemampuan mereka yang sebenarnya. Siswa yang merasa sulit untuk mengembangkan minat siswa, meminta bantuan teman lain yang sudah mengerti. Pada saat itu siswa untuk berkomunikasi dan juga secara bersamaan mengembangkan

kemampuan komunikasinya. Pada saat siswa mengalami kesulitan, maka guru akan siap membantu menyediakan scaffolding untuk membantu para siswa ini.

Sementara itu, melalui diskusi dengan teman-teman bangku atau meminta guru dan dibahas di kelas bersama-sama, kemampuan potensi siswa lebih berkembang sehingga siswa lebih termotivasi melaui media pembelajaran fikih berbasis Adobe Flash ini.

Analisis statistik menunjukkan bahwa ada perbedaan yang signifikan antara siswa yang menerima pembelajaran Adobe Flash dengan siswa yang mendapat pembelajaran konvensional, dari semua pengolahan data terlihat rata-rata minat

${ }^{21}$ Dahlan, J.A, Kusumah, Y.S., Sutarno, H. (2009). Pengembangan Model Computer Based ELearning untuk Meningkatkan Kemampuan HighOrder Mathematical Thinking Siswa SMA. Penelitian Hibah Bersaing Perguruan Tinggi. Universitas Pendidikan Indonesia: Dikti. 
dan motivasi siswa kelas eksperimen lebih tinggi dari kelas konvensional.

\section{E. KESIMPULAN}

Berdasarkan hasil penelitian dan pembahasan di atas, dapat disimpulkan:

1. Ada perbedaan yang signifikan antara kelas kontrol dan kelas eksperimen.

2. Peningkatan hasil belajar eksperimental siswa lebih baik daripada kelas kontrol. Pembelajaran dengan pembelajaran media Adobe Flash direkomendasikan untuk diterapkan dalam proses pembelajaran fikih di Madrasah Aliyah Negeri.

\section{DAFTAR PUSTAKA}

\section{Sumber dari Jurnal}

Dahlan, J.A., Kusumah, Y.S., dan Sutarno, H. (2009). Pengembangan Model Computer Based E-Learning untuk Meningkatkan Kemampuan HighOrder Mathematical Thinking Siswa SMA. Penelitian Hibah Bersaing Perguruan Tinggi. Universitas Pendidikan Indonesia: Dikti.

Maya, R. (2016). Revitalisasi Keteladanan dalam Pendidikan Islam: Upaya Menjawab Peluang dan Tantangan Pendidikan Islam di Era Masyarakat Ekonomi ASEAN (MEA). Edukasi Islami: Jurnal Pendidikan Islam, 05(9).

Maya, R. (2018). Implikasi Relasi Eksploratif ('Alâqah Al-Taskhîr) dalam Pendidikan Islam: Telaah Filosofis Atas Pemikiran Mâjid 'Irsân Al-Kîlanî. Edukasi Islami: Jurnal Pendidikan Islam, 07(2).
Sholichah, A.S. (2018). Teori-Teori Pendidikan dalam Islam. Edukasi Islami: Jurnal Pendidikan Islam, 07(1).

Suryadi, E., Ginanjar, M.H., dan Priyatna, M. (2018). Penggunaan Media Sosial Whatsapp dan Pengaruhnya Terhadap Disiplin Belajar Peserta Didik pada Mata Pelajaran Pendidikan Agama Islam. Edukasi Islami: Jurnal Pendidikan Islam, 07(1).

Tanjung, H.B. (2015). Menyelamatkan Nasib Anak Bangsa dengan Pendidikan Islam. Edukasi Islami: Jurnal Pendidikan Islam, 04(08).

Wahidin, U. dan Syaefuddin, A. (2018). Media Pendidikan dalam Perspektif Pendidikan Islam. Edukasi Islami: Jurnal Pendidikan Islam, 07(1).

Wahidin, A. (2016). Pemikiran Pendidikan Al-Albani. Edukasi Islami: Jurnal Pendidikan Islam, 05(9).

Wahidin, U. (2018). Implementasi Literasi Media dalam Proses Pembelajaran Pendidikan Agama Islam dan Budi Pekerti. Edukasi Islami: Jurnal Pendidikan Islam, 07(2).

\section{Sumber dari Buku}

Anita, S. (2009). Media Pembelajaran. Surakarta: Yuma Pustaka.

Madcoms. (2012). Kupas Tuntas Adobe Flash Profesional CS6. Yogyakarta: CV Andi Offset.

Munadi, Y. (2013). Media Pembelajaran: Sebuah Pendekatan Baru. Jakarta: Gang Persada Pers.

Syarifuddin, A. (2009). Ushul Fiqih. Jakarta: Kencana. 